\title{
Individual and Population Energy Budgets of the Water Vole
}

\author{
Kenneth R. ASHBY \& Malcolm A. VINCENT
}

\begin{abstract}
Ashby K. R. \& Vincent M. A., 1976: Individual and population energy budgets of the water vole. Acta theriol., 21, 34: 499-512 [With 2 Figs.].

Energy budges of individuals of the water vole Arvicola terrestris amphibius (Lin n a e s, 1758) were computed from records of activity patterns and temperature experience in enclosures in the field and from measurements of the oxygen usage at differing temperatures, seasons and levels of activity in the laboratory. The proportion of the diel period spent outside the nest was constant at $25 \%$ from September to April, then increased to reach a peak of $38 \%$ in July and subsequently returned to the overwintering level. Strenuous activities occupied $15 \%$ of the time spent outside the nest. The $A D M R$ of overwintering individuals of $180 \mathrm{~g}$ averaged $0.23 \mathrm{kcal} / \mathrm{g} /$ day. There was a slight net increase of $A D M R$ in summer. Live trapping, microscopical study of faeces and sampling of the vegetation along $400 \mathrm{~m}$ of stream provided analyses of population dynamics, diet, and primary productivity within the feeding range. This extended no more than $1 \mathrm{~m}$ from the water's edge. It is estimated that energy assimilated was about $2000 \mathrm{Mcal} / \mathrm{ha}$ year of feeding range and in the order of $20 \%$ of its primary productivity. Secondary production was about $4 \%$ of the energy assimilated.
\end{abstract}

[Univ. Durham, Dept. Zool., South Rd, Durham DH1 3LE, England].

\section{INTRODUCTION}

Although abundant, the water vole has until very recently been the subject of little ecological research. Furthermore, since water voles like other herbivorous or polyphagous cricetid rodents, can have highly variable levels and patterns of activity (A s h by, 1972; S e w e 11, 1973; Greenwood, 1974; Knight, 1975), considerable caution needs to be exercised when extrapolating data obtained from laboratory studies on the energetics of the species to field conditions. Consequently it has been impracticable to assess the trophic-dynamic significance of the species. The present research concerns a population energy budget for the main British sub-species of the water vole, based as far as practicable on data obtained from a wild population or from individuals confined under semi-natural conditions (V incent, 1974). D r o żd $\dot{z}$, Górecki, Grodziński \& Pelikán (1971) and Erdakov (1972) published the results of parallel studies while it was in progress.

[499] 


\section{METHODS}

The population structure of water voles on both banks of a $400 \mathrm{~m}$ length of slowly flowing stream three metres wide situated $16 \mathrm{~km}$ south of Durham City at map reference NZ 296 264, was monitored during 1971 and the autumn and early winter of $1972-73$ by live-trapping at intervals averaging ten days in summer and one month in winter. Individuals were marked with numbered ear tags made of monel metal. It is estimated that the mean capture rate was as high as $80 \%$ of the population per 24 hours.

The diet was determined by microscopical analysis of faeces collected from the latrines, which were distributed at intervals alongside the stream. The feeding range was determined by observing the area of significant grazing pressure. The dry weight of primary production within it was determined according to the methods described by Weigert \& Evans (1964), and converted to the calorific equivalent by multiplying the ash-free dry weight by 4.5 . The digestibility coefficient of the diet has been assumed to average $50 \%$ on the basis of determinations

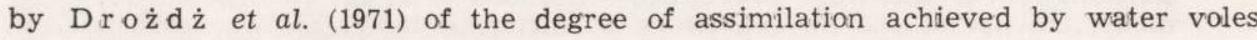
fed on grass and other plant material.

The parameters of daily activity and temperature experience in the field were studied by the use of enclosures $3 \times 3 \mathrm{~m}$ in area made at the side of a small stream $2 \mathrm{~km}$ south of Durham. Each of these contained an artificial burrow dug into the bank of the stream of similar dimensions to the natural burrows of water voles described by Ryder (1962) and M. J. Creasy (unpublished), and lined with wire-neting to prevent it being extended by the vole. Individuals, or occasionally pairs of voles, introduced into the enclosures readily took up residence in the artificial burrows and made nests in the terminal chambers which were $20 \mathrm{~cm}$ below the surface of the ground. The temperature of the air both outside these burrows and at a lateral position inside each nesting chamber was monitored by Cambridge recording thermographs. The air temperature inside the nesting chamber rose or fell sharply when the vole entered or left, and thus provided a continuous record of the occupancy of the chamber. Since the temperature reached an equilibrium within five minutes of a vole's return, the vole's temperature experience within the nest could also be determined. Flowe rdew (1973) has used the same technique for studying the movements of Microtus in and out of the nest. The behaviour of the voles outside the nest was studied from a hide. The time spent outside the burrow was divided into the proportion spent resting, that concerned with activities requiring a low expenditure such as feeding and grooming, and that spent running, digging and swimming which require a high expenditure of energy.

The resting measured in the laboratory by means of a Kalabukhov-Skvortzov respirometer at air temperatures within it of $3^{\circ}, 10^{\circ}, 15^{\circ}, 20^{\circ}$ and $28^{\circ} \mathrm{C}$ in the summer months and $3^{\circ}, 10^{\circ}$ and $15^{\circ} \mathrm{C}$ in winter. The vole was provided with about $18 \mathrm{~g}$ of cotton wool, and given $2.5 \mathrm{hr}$ to acclimatise and make a nest in the respirometer before measurements were made. The increment in energy usage caused by activities requiring a low expenditure of energy was estimated by monitoring the metabolic rate during periods of continuous feeding and grooming. That resulting from more energetic activities was assumed to be the same as has been observed by Grodziński \& Górecki (1967) and by Hansson \& Grodziński (1970) in mice and small voles. 


\section{RESULTS}

\section{Activity and Temperature Experience in the Field}

From September through to March inclusive the proportion of each 24 hours spent outside the nest remained steady at six hours, that is $25 \%$. During the spring the proportion of time spent outside rose, and a peak was reached in July when rather over nine hours per 24 hours or $38 \%$ of the time was spent outside the nest by adult water voles. There was a rapid decline in activity in the late summer, leading by the end of August to a reversion to the situation found during the nonbreeding period.

For most of the year the mean level of activity was more or less uniform throughout the diel period. There were two major deviations from this pattern. Firstly there was a marked reduction in the time spent outside the nest during frosty nights in winter. Secondly the increased activity in summer was confined to the period from two hours after sunset to three hours after sunrise so that at this season activity was most intense during the coolest part of the diel cycle. Another feature of the summer was a marked synchronism of activity with a four to five hourly periodicity, between midnight and midday. Any underlying short term rythm of individuals was much less apparent on the summated records at other times of year and after midday in summer.

Of the periods spent outside the nest in daylight, about $15 \%$ of the time was spent in the activities requiring a high expenditure of energy, that is swimming, diving and burrowing, $57 \%$ in activities requiring a low expenditure of energy and $28 \%$ inactive. It has been assumed that these proportions applied at night also. They did not vary significantly from month to month, so that from an energetic viewpoint the main seasonal changes in activity were firstly the greater proportion of the 24 hours spent outside the insulated environment provided by the nest in summer as compared with the remainder of the year, and secondly the increased proportion of time spent in the nest when the external temperature fell below $0^{\circ} \mathrm{C}$. In terms of the amount of time devoted to it, the most significant activity requiring a low expenditure of activity was feeding. Throughout the year this occupied about $45 \%$ of the time spent outside the nest.

The mean temperature of the nest when occupied, was about $10^{\circ} \mathrm{C}$ from November to March, rose steadily throughout the spring and early summer, fluctuated around $19^{\circ} \mathrm{C}$ from July until early September and then declined. The corresponding range of mean air temperatures close to the ground outside the burrow extended between $2{ }^{\circ} \mathrm{C}$ in January and $14^{\circ} \mathrm{C}$ in early July. The tendency to reduce the proportions of time spent 
outside the nest during the coldest weather in winter and from mid morning to late afternoon in summer, increased the mean air temper:ture actually experienced by voles outside the nest by about $0.5^{\circ} \mathrm{C}$ for much of the winter and reduced it by up to $1.5^{\circ} \mathrm{C}$ during periods if sunny weather in summer.

\section{Resting and Average Daily Metabolic Rates}

The curve obtained for the resting metabolic rate of adults between $3^{\circ} \mathrm{C}$ and $28^{\circ} \mathrm{C}$ in summer and between $3^{\circ} \mathrm{C}$ and $15^{\circ} \mathrm{C}$ in winter is given in Figure 1. The individuals used for constructing these curves were within the weight range of $170 \mathrm{~g}$ to $190 \mathrm{~g}$, which was the size of adults during the non-breeding period. The metabolic rate is expressed as $\mathrm{kcal}^{\mathrm{kg}} \mathrm{kg}^{0.75} /$ day on Figure 1 to make allowance for the modest differences

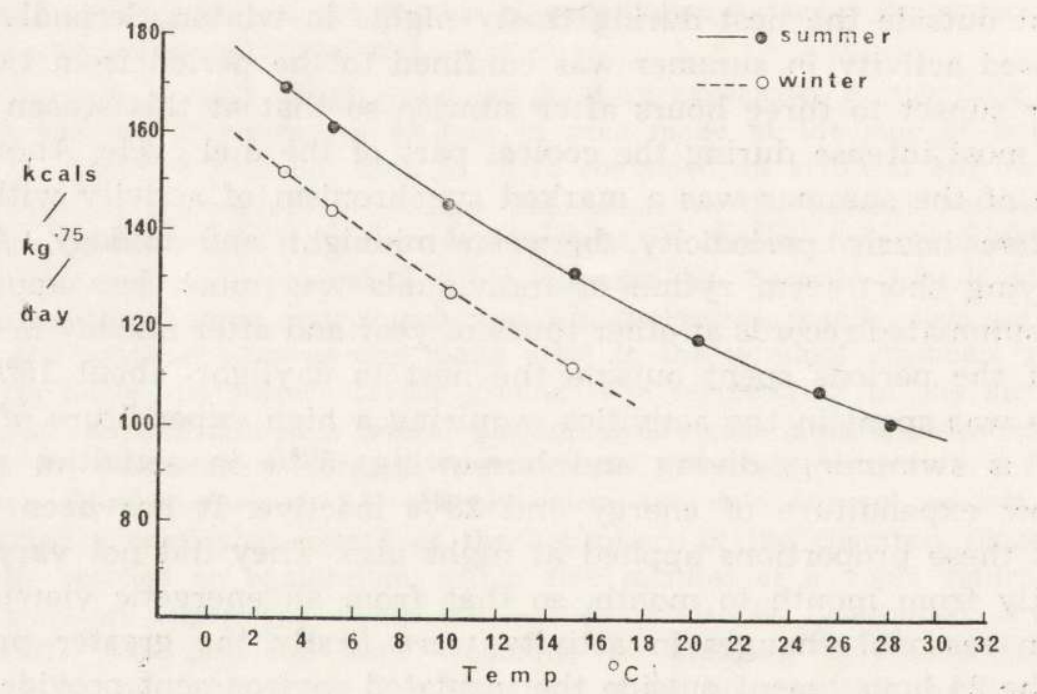

Fig. 1. Variation with temperature of resting metabolic rate of water voles weighing about $180 \mathrm{~g}$, in summer and in winter.

in weight of the experimental animals, on the basis that for most mammals the rate of metabolism per unit weight is a function of the total weight $t^{0.75}$ (K le i be r, 1961). Since the highest temperature tested $\left(28^{\circ} \mathrm{C}\right)$ will have been within or close to the thermoneutral zone, the resting metabolism at this temperature, $0.15 \mathrm{kcal} / \mathrm{g} / \mathrm{day}$, may be taken as an approximation of the basal metabolic rate. During the breeding season the resting metabolic rate of juveniles from the weight of $60 \mathrm{~g}$ (reached shortly after weaning) and upwards, was also determined. At $15^{\circ} \mathrm{C}$ this was in the order of $0.36 \mathrm{kcal} / \mathrm{g} /$ day for individuals of $60 \mathrm{~g}$, 
$0.28 \mathrm{kcak} / \mathrm{g} /$ day for individuals of $100 \mathrm{~g}$ and $0.23 \mathrm{kcal} / \mathrm{g} /$ day for those of $140 \mathrm{~g}$. Oyer the range of temperature from $3{ }^{\circ} \mathrm{C}$ to $15^{\circ} \mathrm{C}$, the resting metabolic rate was about $12 \%$ lower in winter than in summer for adults of a given weight. This may be partly due to the greater thickness of the pelage during the former season reported by B u hlow (1970).

The measurements of the oxygen consumption of water voles engaged in continuous feeding suggested that firstly the metabolic rate during a period: of activity requiring a low expenditure of energy was in the order 1.64 times that of the resting metabolic rate at $15^{\circ} \mathrm{C}$ in winter, and secondly that it showed little variation with change of environmental temperature. For activities requiring a high expenditure of energy, the corresponding factor at $15^{\circ} \mathrm{C}$ has been assumed to be 2.52 , as a mean figure based on the data concerning the effect of strenuous activity on the metabolic rate of small species of vole given by Grodziński \& Górecki (1967) and Hansson \& Grodziński (1970). The metabolic rates during activity have been assumed to be the same in summer and in winter, given their independence of environmental temperature.

From the combined data on activity, temperature experience, resting metabolic rate and increments in energy usage resulting from activity, and given that moulting occurs at the end of April and of October, the daily metabolic rate and daily energy budget of a non-breeding water vole weighing $180 \mathrm{~g}$ has been calculated. The resulting estimates fluctuate around a value of $0.23 \mathrm{kcal} / \mathrm{g} / \mathrm{day}$ and a little under $42 \mathrm{kcal} /$ individual/day, from the end of August through until the end of the following April. They are raised about $3 \%$ from May to early August, to values of about $0.24 \mathrm{kcal} / \mathrm{g} /$ day and $43 \mathrm{kcal} /$ individual $/$ day. The rise during the late spring and much of the summer results from the increased level of activity at that time more than balancing the decrease in resting metabolic rate caused by the higher environmental temperature. If the seasonal change in activity outside the nest is discounted, the net effect of the difference in temperature experience in summer and in winter combined with the thicker pelage at the latter season, is calculated to be a rise in the average metabolic rate of $6 \%$ in mid winter in comparison with mid summer:

\section{Population Energy Budget and Primary and Secondary Production}

During the winter and spring of $1970-71$, the population density was in the order of one adult per $75 \mathrm{~m}$ of stream, while the winter of 1972 73 commenced with about one adult per $50 \mathrm{~m}$ of stream. Approximately one third of the adults overwintering from 1971 to 1972 and forming the 
breeding population in 1972 were still alive at the end of December 1972. There were two cohorts of litters in 1971. The first resulted from synchronous pregnancies during May leading to the offspring entering the trappable population at the end of June. The young of this cohort grew extremely rapidly, weighing $160 \mathrm{~g}$ five weeks after birth and $185 \mathrm{~g}$ six weeks later. The second cohort was born four to five weeks after the first. The offspring in this case grew less rapidly and took about five months following weaning to reach a weight of $170 \mathrm{~g}$. There remained a difference of about $20 \mathrm{~g}$ in the mean weights of individuals of the two cohorts for much of the winter. One instance only was encountered of a young vole breeding during the year in which it was born.

Growth recommenced with the attainment of sexual maturity in April of the year following birth, and by the commencement of breeding the weight had increased to about $250 \mathrm{~g}$ in males and $230 \mathrm{~g}$ in nonpregnant females. No individual survived to breed a second year during the study. Approximately equal numbers of individuals survived from each of the litters into the following year.

The data on the various components of the daily energy requirements of adult voles combined with firstly the data on the breeding pattern, growth of young and composition of the population throughout the year, secondly the resting metabolism of the various stages of growth after weaning and thirdly the energy costs of pregnancy and lactation given by $\mathrm{Kaczmarski}$ (1966) and Migula (1969), permitted the calculation of the population metabolism for the area studied. This is given for periods of 20 days throughout the year in Figure 2. The authors have assumed, like Drożd $\dot{z}$ et al. (1971), that the costs of pregnancy and lactation bear the same relation to the maintenance metabolism in water voles as in Clethrionomys and Microtus.

The area used for feeding as determined by observations on the occurrence of grazing, extended for only one metre from the water's edge on either side of the stream. This observation accords with the more extensive study by Ryder (1962) on this matter. Over the length of stream studied, the primary production of this zone available as food to the voles, that is including the material which they consumed, was estimated to be $19,500 \mathrm{Mcals} / \mathrm{ha} / \mathrm{year}$. There was in addition in the order of $1000 \mathrm{Mcals} / \mathrm{ha} / \mathrm{year}$ of primary aerial production not available to the voles made up of plant species which were spiny, poisonous or simply distasteful. As the underground parts of plants were not eaten to any extent, production by the root systems was not estimated.

The energy assimilated by the water voles was about $2000 \mathrm{Mcals} / \mathrm{ha} /$ yeax and that converted into vole tissue is estimated at $80 \mathrm{Mcals} / \mathrm{ha} / \mathrm{year}$. The diet consisted predominantly of grasses, these making up about $80 \%$ 
of the food by volume in the winter, $65 \%$ in the spring and about $90 \%$ in the summer and autumn. Over the year as a whole a further $7 \%$ consisted of the stinging nettle Urtica dioica. The dead nettle Lamium album was important in the winter and spring, when it formed 7 and $22 \%$ of the diet respectively. The balance was made up by a variety of

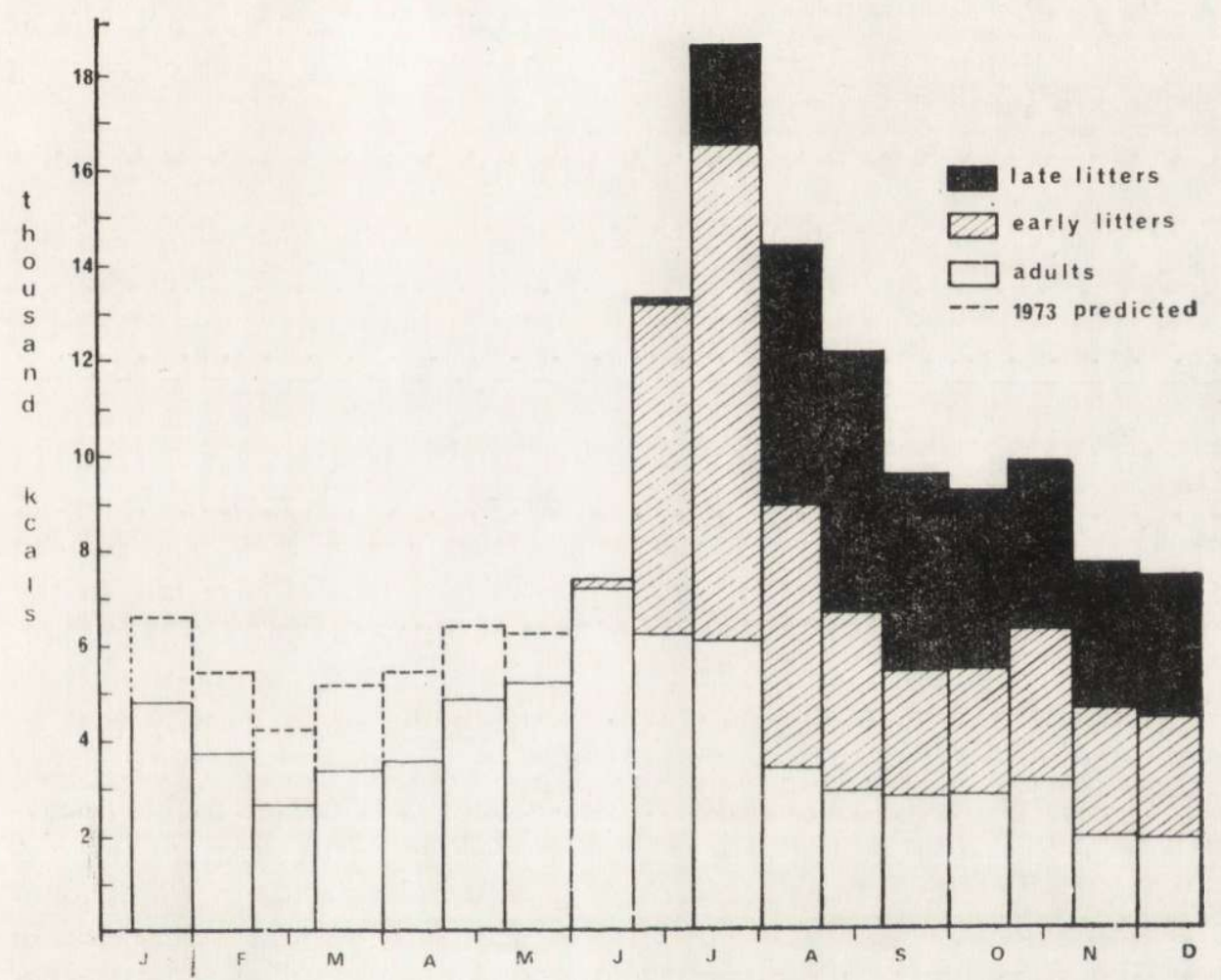

Fig. 2. Population metabolism of water voles inhabiting banks of $400 \mathrm{~m}$ length of stream, calculated for successive periods of 20 days throughout the year.

The unshaded columns with a continuous outline indicate the metabolism during 1971 of individuals born in 1970 . The dotted sections indicate the metabolism during the winter and spring of 1973 estimated on the basis of the rather higher population level observed in December 1972 and assuming the same rate of survival in these seasons as in 1971. The cross-hatched portions represent the contribution during 1971 from the first cohort of litters, which were born in early to mid June of that year, and the solid shading that from the second litters which were born in mid July.

other forbs. For the percentage of energy assimilated by water voles fed on a variety of foods, D rożd ż et al. (1971) give values of $47.7 \%$ for grass and from $66.8 \%$ to $87.7 \%$ for the other foods tested. E r dakov (1972) quotes a mixed diet including bulrush as being $50.3 \%$ assimilated. 
If in the present instance, grass is assumed to be $50 \%$ assimiliated and the remaining foods $75 \%$ assimilated, the amount of food eaten by the population will have totalled about $3,600 \mathrm{Mcals} / \mathrm{ha} / \mathrm{year}$. If the overall assimilation rate was in fact as low as $50 \%$, the amount ingested will have been $4000 \mathrm{Mcals} / \mathrm{ha} /$ year. These figures suggest that within the feeding range, the water voles were ingesting in the order of $20 \%$ of the aerial primary production, assimilating about $10 \%$ of it and converting about $0.40 \%$ of it into tissue.

\section{DISCUSSION}

The water vole has been variously reported to be primarily diurnal (R y d e r, 1962; C or bet, 1966; S t od d a r t, 1969; L u n d, 1970), diurnal and crepuscular (W i jng a a d en, 1954), crepuscular (C. H. Worrall, see $\mathrm{S}$ ou thern, 1964), and nocturnal (D rożd ż et al. 1971). The predominant pattern in the present observations of activity being more or less evenly distributed over the diel period was observed by $\mathrm{D} \mathrm{u} \mathrm{ckett}$ (1969) in the laboratory in March 1969 and A shby, Harling \& Whiles (1969) in the field in May and early June of 1967 . The pattern occurring in the summer in the present study of a maximum late in the night and into early hours of daylight was observed by M. J. Creasy and M. J. Duckett (see Duckett, 1969; A shby, 1972) along the River Wear in June 1969. Knight (1975) found in the same locality that in the summer of 1974 the pattern had become one of activity being greatest before sunset and following dawn and minimal at night, apparently because Rattus norvegicus had spread into the area. Greenw o od (1974) likewise has reported the nocturnal activity of Clethrionomys glareolus to be inhibited in the presence of Apodemus sylvaticus. In the laboratory both D u ckett (1969) and Knight (1975) found water voles to be primarily nocturnal in summer.

Such changes in the distribution of activity over the diel cycle will affect the energy budget by altering temperature experience. Any major alteration in the total amount of activity as a result of confinement (F a lls, 1968; A s h by, 1972) and likewise in its intensity, is likely to cause a more substantial alteration of energy expenditure. This latter factor may be responsible for energy budgets of Peromyscus maniculatus (S a d leir, Casperson \& Harling, 1973) and of Clethrionomys glareolus and Apodemus sylvaticus (K. R. Ashby, N. H. Cleminson \& M. C. Crawley unpublished) as calculated from field data, being higher than in estimations based on activity levels observed in the laboratory such as those of Grodziński et al. (1970).

The present values for the proportion of time spent by water voles outside the nest may be accepted as best estimates in the absence of 
quantitative data from the field. The mean of $25 \%$ observed during most of the year is close to that of $23 \%$ given by $\mathrm{D} \mathrm{r}$ o $\dot{\mathrm{z}} \mathrm{d} \dot{\mathrm{z}}$ et al. (1971), while the increase in the proportion of time spent active with the approach of summer accords with the experience of D u ckett (1969). The peak of $38 \%$ does not differ greatly from the estimate of $45 \%$ in July made by $\mathrm{Knight}$ (1975) on the basis of actograph records. $\mathrm{Ham}$ a r et al. (1970) reported $37.5 \%$ of the diel period to be spent outside the nest by Arvicola terrestris scherman, but did not specify the time of year when observations were made. The figure of $15 \%$ of the time outside the nest being devoted to strenuous activities may well however be lower than the mean in the field. S. Vybíral (see D rożd ż et al. 197.1) estimated at least $25 \%$ of it to be spent swimming. Furthermore the home range can exceed $200 \mathrm{~m}$ in length (W or r a 1l, 1964; J. Capes and J. M. Picken unpublished), which if it is well patrolled likewise indicates a high level of strenuous activity.

At thermoneutrality adults of $100 \mathrm{~g}$ in the present study had a resting metabolism of $27.5 \mathrm{kcal} /$ day, while in adults of $100 \mathrm{~g}$ of the sub-species ușed by $\mathrm{D} \mathrm{rożd} \dot{z}$ et al. (1971), this was $18.6 \mathrm{kcal} /$ day. The data concerning the metabolism of Clethrionomys glareolus given and reviewed by Gór e cki (1968) and the corresponding data for Microtus agrestis given by $\mathrm{H}$ ans son \& Grodzińs ki (1970) suggest a resting metabolism at thermoneutrality for a small species of vole of $20 \mathrm{~g}$ of about $6.6 \mathrm{kcal} / \mathrm{day}$, although a considerable range of values around this level has been given by various authors. The three values given above for adult voles ranging in size from 20 to $180 \mathrm{~g}$ vary as weight ${ }^{0.66}$, as compared with the standard relation in mammals of metabolism under basal conditions varying as weight ${ }^{0.75}$ ( $\mathrm{K}$ l e i b e r, 1961).

As the rise in metabolism at temperatures below thermoneutrality is determined by thermal conductance varying as weight ${ }^{-0.50}$ ( $\mathrm{Grodzi}$ nski \& W under, 1975), the proportionate increase in metabolism with decline of temperature will become greater as body size decreases. The metabolism of the present adults of $180 \mathrm{~g}$ in summer pelage was $80 \%$ higher at $0^{\circ} \mathrm{C}$ than at thermoneutrality, as against being more than doubled in those of about $100 \mathrm{~g}$ used by Drożd $\dot{z}$ et al. (1971). Grodziński \& W under (1975) conclude that in most rodents and insectivores, $A D M R$ likewise varies as weight ${ }^{-0.50}$. In the present instance a relation of resting metabolism varying as weight ${ }^{0.50}$ was in fact observed at all environmental temperatures. This observation was linked with the mean resting metabolism at thermoneutrality of juveniles of $100 \mathrm{~g}$ being $20.6 \mathrm{kcal} /$ day and thus $10 \%$ greater than that for adults of this weight used by D r o żd ż et al. (1971). These authors likewise found resting metabolism within their samples to vary approximately as 
weight ${ }^{0.50}$ even at thermoneutrality, and that the presence of juveniles in a sample of given average weight used for estimating $A D M R$ led to a substantially higher value for this parameter than if it was extrapolated from observations on adults on the assumption of metabolism being proportional to weight 0.75 . The values for $A D M R$ given by $\mathrm{Erdak}$ ov (1972) are in accord with those given by $\mathrm{D}$ rożd ż et al. (1971).

The need to ensure good nutrition while minimising specific dynamic action, together with the possibility on the one hand of sleep reducing metabolism below the standard resting level and on the other of metabolism being increased through supposedly resting individuals in fact being agitated, both contribute to the difficulty of determining the metabolic parameters of small mammals. B a shenin a (1969) found that at thermoneutrality, specific dynamic action could equal basal metabolism in mouse-sized species. D ro żd ż et al. (1971) observed the resting metabolism of water voles to fall nearly $30 \%$ following a few hours without food. Hanss on \& Grodzins ki (1970) suggested that sleep was the factor responsible for the observed ADMR of Microtus agrestis being $30 \%$ below the resting metabolic rate at $20^{\circ} \mathrm{C}$. The combination of a diet fairly low in protein with the removal of food three hours before determining oxygen usage, was intended to minimise the net effect of specific dynamic action combined with any reduction of metabolism through depletion of glycogen reserves during fasting. Given the presence of a well-formed nest in the metabolic chamber during the test periods and the absence of any sign of agitation on the part of individual voles, there is no reason for suspecting that the proportion of time spent asleep during these periods deviated from the normal level for individuals when in the nest. In Clethionomys this appears to be about half of the time spent there (A s h b y, 1972; S e w e ll, 1973).

The absence of data on the normal frequency of huddling affects the estimate of population metabolism only slightly. The value given by D rożd ż et al. (1971) of huddling in threes reducing the daily metabolism of adult water voles of $100 \mathrm{~g}$ by $4 \%$ at $20^{\circ} \mathrm{C}$, can be applied in the present instance, since the relation between the ratio of the resting metabolism at thermoneutrality to that at $20^{\circ} \mathrm{C}$ for the voles they used, will be the same as that between the values at thermoneutrality and at $14^{\circ} \mathrm{C}$ with present larger adults. This latter temperature was in fact the annual mean in the nest.

A notable feature of the population ecology was the high density and biomass in relation to the size of area used for grazing, the latter ratio reaching $50 \mathrm{~kg} / \mathrm{ha}$ in late July towards the end of the breeding season. According to the synopsis of data in Tables 4.2 and 12.2 of Golley, Petrusewicz \& Ryszkowski (1975), this is close to the upper 
limit of biomass in relation to size of feeding area found in small mammals. Similarly the proportion of the primary production within the grazing area consumed, was higher by a factor of ten than is general in rodents according to the data given in Table 10.1 of Golley et al. (1975) and close to the highest value recorded. However, the energetic efficiency of production of a little over $2 \%$ was close to the mean in small mammals (see page xxi in Golle y et al. 1975). The restriction of grazing to the immediate vicinity of the water's edge was behavioural in origin: similar herbage continued up the banks of the stream. Possibly the heavy cropping, by encouraging growth of young grass and forbs in an area flushed by water rich in mineral nutrients and silt during the periodic rises in stream level, improved the palatability of the herbage by producing a regime similar to water meadows. The net effect of feeding being confined to the area near the water's edge is to limit grazing to a zone of considerable productivity but no agricultural significance, and result in the water vole in Britain causing little economic damage in spite of its abundance.

A further feature of the population dynamics was the shortness of the breeding season, associated with good breeding success and relatively low overwintering mortality. The number of litters was at the lower limit of that recorded in water voles by other authors. Stoddart $(1968,1971)$ observed a mean close to two litters per breeding season in eastern Scotland, D r o żd ż et al. (1971) and P. A. Pantaleev (see Table 4.2 in Golle y et al. 1975) means of about three in central Europe and the U.S.S.R. respectively, Southern (1964) records one of 4.4 for Holland while R y der (1962) suggested that breeding generally continued throughout the summer and into September in England. As a mean of nine offspring per pair entered the population from the two litters combined, the survival curves for the population of water voles studies therefore fell between that for moderate and high survival rates for small mammals as illustrated in Figure 4.1 of G o lle y et al. (1975).

Acknowledgement: Dr. M. A. V incent was financed during his research by a studentship given by the Natural Environment Research Council. The material of the present paper was presented at the Fourth Meeting of the IBP Working Group on Small Mammals Warsaw 6-10 November 1973.

\section{REFERENCES}

1. Ashby K. R., 1972: Patterns of daily activity in mammals. Mamm. Rev, 1: $171-185$.

2. Ashby K. R., Harling J. \& Whiles D., 1969: Observations on the distribution and activity of water voles (Arvicola amphibius amphibius) in old Durham Beck, Durham. J. Zool., Lond., 158: 209-214.

3. Bashenina N. V., 1969: Basic bioenergetic indices in small nonhibernating mammals in natural populations. [In: „Energy flow through small mammal 
populations«, Ed. K. Petrusewicz, \& L. Ryszkowski]. Polish Sci. Publ.: 167177. Warszawa.

4. Buhlow E., 1970: Untersuchungen über den Haarwechsel bei Schermausen Arvicola terrestris (L. 1758). Zool. Anz., 184: 18-32.

5. Corbet G. B., 1966: The terrestrial mammals of western Europe. Foulis: 1264. London.

6. Drożdż A., Górecki A., Grodziński W., Pelikán J., 1971: Bioenergetics of water voles (Arvicola terrestris L.) from southern Moravia. Ann. zocl. Fennici, 8: 97-103.

7. D u ckett M. J., 1969: A study of activity in the water vole Arvicola terrestris. pp 1-57. Dissertation, Faculty of Science, University of Durham.

8. Erdakov L. N., 1972: Potreblenie energii i koefficient utilizacii pišči u obyknovennogo homjaka i vodjanoj krysy. Ekologija, 3: 66-69.

9. F a 11 s J. B., 1968: Activity. [In: »Biology of Peromyscus (Rodentia)«, Ed. J. A. King]: 543-570. The American Society of Mammalogists, Special publication No. 2.

10. Flowerdew J. R., 1973: A new method for recording the activity of small mammals in the field. J. Zool., Lond., 171: $449-455$.

11. Golley F. B., Petrusewicz K. \& Ryszkowski L., Eds, 1975: Small mammals: their productivity arid population dynamics. University Press: $\mathrm{XXV}+1-451$, Cambridge.

12. Górecki A., 1968: Metabolic rate and energy budget in the bank vole. Acta theriol., 13: $341-365$.

13. Greenwood P. J., 1974: The activity of the bank vole, Clethrionomys gla. reolus, and the wood mouse, Apodemus sylvaticus, pp. 1-89. Dissertation, Faculty of Science, University of Durham.

14. Grodziński W., Bobek B., Drożdż A. \& Górecki A., 1970: Energy flow through rodent populations in a beech forest. [In: "Energy flow through small mammal populations«, Ed. K. Petrusewicz \& L. Ryszkowski]. Polish Sci. Publ.: 291-298. Warszawa-Kraków.

15. Grodziński W. \& Górecki A., 1967: Daily energy budget of small rorents. [In: »Secondary productivity of terrestrial ecosystems«, Ed. K. Petruscwicz]. Polish Sci. Publ.: 1: 295-314. Warszawa-Kraków.

16. Grodziński W. \& Wunder B. A., 1975: Ecological energetics of small mammals. [In: "Small mammals: their productivity and population dynamics, Eds F. G. Golley, K. Petrusewicz \& L. Ryszkowski]. Cambridge University Press: 173-204. Cambridge.

17. H a mar M., Suteu G., Sutova M. \& Tuta A., 1970: Determination of the structure and use of underground galleries of Arvicola terrestris scherman Shaw and Pitymys subterraneus de S. L. by "Co Co labelling. EPPO Public. Ser. A, No. 58: $129-135$.

18. Hans on L. \& Grodziński W., 1970: Bioenergetic parameters of the field vole Microtus agrestis L. Oikos, 21: 76-82.

19. Ka c z marski F., 1966: Bioenergetics of pregnancy and lactation in the bank vole. Acta theriol., 11: 409-417.

20. Kleiber M., 1961: The fire of life - an introduction to animal energetics. J. Wiley: $1-454$. New York.

21. Knight D. A., 1975: Some aspects of activity of the water vole, Arvicola terrestris and the brown rat, Rattus norvegicus. pp. 1-112. Dissertation, Faculty of Science, University of Durham. 
22. Lund M., 1970: Diurnal activity and distribution of Arvicola terrestris: terrestris L. in an outdoor enclosure. EPPO Public. Ser. A, No. 58: $147-158$.

23. Migula P., 1969: Bioenergetics of pregnancy and lactation in the European common vole. Acta theriol., 14: 167-179.

24. Ryder S. R., 1962: Animals of Britain, 4 - Water Voles. Sundáy Tìmes Publications: $1-25$. London.

25. S a d le ir R. M. F. S., C a spers on K. D. \& H a rling J., 1973: Intake and requirements of energy and protein for the breeding of wild deermice (Peromyscus maniculatus). J. Reprod. Fert., Suppl., 19: 237-252.

26. Sewell P. I. V., 1973: Activity patterns and behaviour of Clethrionomys glareolus. pp. 1-261. Thesis, Faculty of Science, University of Durham.

27. Southern H. N., 1964: The handbook of British mammals. Blackwell: 1-565. Oxford.

28. Stoddart D. M., 1968: An ecological study of Arvicola terrestris (L.) with particular reference to population dispersion. Thesis, University of Aberdeen.

29. Stoddart D. M., 1969: Daily activity cycle of the water vole (Arvicola terrestris). J. Zool., Lond., 159: 538-540.

30. Stoddart D. M., 1971: Breeding and survival in a population of water voles. J. Anim. Ecol., 40: 437-494.

31. Vincent M. A., 1974: Energy utilisation and activity patterns of the vole Arvicola terrestris amphibius (L.). pp. 1-464. Thesis, Faculty of Science, University of Durham.

32. Weigert R. G. \& Evans F. C., 1964: Primary production and the disappearance of dead vegetation on an old field in Southeastern Michigan. Ecology, 45: $49-63$.

33. Wijng a a r d e n A. van, 1954: Biologie en bestrijding van de woelrat Arvicola terrestris (L.). in Nederland. Meded. plziektenk. Dienst Wageningen, 123: $1-147$.

34. Worra 11 C. H. B., 1964: Some observations on a population of the water-vole (Arvicola terrestris amphibius). Proc. zool. Soc., Lond., 143: 336-345.

Accepted, March 11, 1976.

Kenneth R. ASHBY i Malcolm A. VINCENT

\section{OSOBNICZE I POPULACYJNE BUDŻETY ENERGETYCZNE KARCZOWNIKA}

\section{Streszczenie}

Dane o aktywności oraz temperaturze środowiska zbierano przy użyciu zagród o wymiarach $3 \times 3 \mathrm{~m}$, ustawionych na powierzchni zamieszkiwanej przez naturalną populację karczownika, Arvicola terrestris amphibius (L i n n a e u s, 1758) w północnej Anglii. W laboratorium mierzono zużycie tlenu w różnych temperaturach i przy zróżnicowanej aktywności, w poszczególnych sezonach roku (Ryc. 1). W okresie od września do kwietnia zwierzęta spędzają $25 \%$ czasu doby poza gniazdem, następnie okres ten wydłuża się i osiąga $38 \%$ czasu doby w lipcu, po czym ulega skracaniu. Intensywna aktywność zajmuje gryzoniowi około $15 \%$ czasu przebywania poza 
gniazdem. Sredni dobowy metabolizm przezimowujących osobników o ciężarze $180 \mathrm{~g}$ wynosi $0,23 \mathrm{kcal} / \mathrm{g} /$ dobę. Latem wartość ta jest nieco niższa.

Odłowy żywych zwierząt, mikroskopowe badania kału i próbek roślin rosnących wzdłuż strumyka, gdzie żyły karczowniki, dostarczyły danych o dynamice populacji i pokarmie gryzoni, a także produkcji pierwotnej żerowisk karczownika. Powierzchnia ta rozciąga się wzdłuż cieku i nie przekracza pasa o szerokości $1 \mathrm{~m}$ od brzegu rzeczki. Oszacowano, że energia pobrana przez karczowniki wynosi około 2000 Mcali /ha/rok, co stanowi około $20 \%$ produkcji pierwotnej, z czego w tkankach odłożone zostało około $80 \mathrm{Mcal} / \mathrm{ha} / \mathrm{rok}$ (Ryc. 2). 